[[SHORT TITLE: A method for postcolonial development geography?]]

\title{
Towards a method for postcolonial development geography? Possibilities and challenges
}

\author{
Parvati Raghuram $^{1}$ and Clare Madge ${ }^{2}$ \\ ${ }^{1}$ Department of Geography, The Open University, Milton Keynes, UK \\ ${ }^{2}$ Department of Geography, University of Leicester, Leicester, UK \\ Correspondence: Parvati Raghuram (email: P.Raghuram@open.ac.uk)
}

In this paper we explore the contours of a 'method' for postcolonial development geography, which makes it possible to imagine another 'world-picturing'. We suggest three steps towards such a method. First, we propose that a postcolonial method involves thinking about why we are doing research in the south in the first place; how we come to and produce our questions; and how we analyze and represent our findings based on our subject positionings. Second, that we need to recognize theorization as an inherent part of method, rethink how we currently theorize and reconfigure our methods of theorization to address wider political aims. Problematizing theorization helps challenge the universalism of Eurocentric theories, thus enabling development geography to move towards more decolonized versions and visions. Finally, that this must be accompanied by firmer recognition of our multiple investments - personal, institutional and geopolitical - and how they frame the possibilities for change. These are some possible steps that we think can reconfigure the 'scholarly track' that postcolonial development geographers traverse.

Keywords: development geography, postcolonial, method, dialogue, theory, British neoliberal academy

\section{Introduction}

In this paper we explore the possibility of a 'method' for postcolonial development geography. ${ }^{1}$ Recently there has been increasing interest in the potentials that a postcolonial perspective offers geography and its subdisciplines (Nash, 2002; King, 2003; Robinson, 2003; Yeoh, 2003; Radcliffe, 2005). Power et al. (2006), for example, suggest that the nexus between development and postcolonialism is a particularly fertile one, which helps to embed postcolonial theory in material practices (Abrahamsen, 2003; McEwan, 2003) while also providing an umbrella under which to incorporate (newer?) inductive development theories that have followed the postdevelopment impasse. However, despite a great deal of work theorizing postcolonial positions, we still lack a thorough and detailed discussion about what a postcolonial method might look like, the issues we should consider while deploying such a method, what problems might arise, and how these might be overcome. ${ }^{2}$ In particular, how can the 'colonial present' (Gregory, 2004) of one contemporary practice of imperialism - that of why, how and what we research - be decentred and relocated to make development research more postcolonial? In this paper we begin to address some of the questions. ${ }^{3}$ 
Right at the outset it must be said that developing this postcolonial method involves complex and potentially contested processes that require recognition of the specificities of historical and spatial production of inequalities in particular places, thoroughgoing dialogue with those who inhabit these places, and willingness to challenge existing hierarchies. A commitment to take up issues raised by those who are researched, a willingness to engage in constructive dialogue that takes into account the conceptual landscape of those with whom we engage, as well as a desire to participate in emancipatory politics are all necessary if we are to get outside of a what Sidaway (2000a:606) terms as Eurocentric 'world-picturing'.

Some of the contours of such a method may be traced in research that development geographers have engaged in, particularly during the past decades. For instance, there is exemplary contemporary research, which arises from and speaks to the issues raised by the researched (see for example Townsend, 1995; Peake \& Trotz, 2002) and reports collaborative research that works across many axes of difference (Pratt, 2002; Monk et al., 2003; Nagar \& Ali, 2003). However, our paper arises out of concern that such practices are not very widespread. As Briggs and Sharpe (2004: 664; original emphasis) argue, in most research, 'the experiences of the marginalized are used in the West, but without opening up the process to their knowledges, theories and explanations'. We therefore want to think through some of the issues that face us in trying to practice postcolonial research and about the moves that may be necessary to open up the process of research so that it enables another world picturing.

The rest of the paper is divided into three sections. Following this introduction, we place our research in the context of relevant debates in the literature on postcolonialism, development geography and method. In the second section we explore three key ways in which method may be expanded to make development research more postcolonial. First, we argue for the need to think about the politics behind the process of 'producing' research questions and how these might ideally arise out of dialogue with the research subjects. Second, we explore why the ways in which we usually deploy academic theories are limited and exclusionary and how the practice of theory needs to be modified to address the materialities of the (post)colonial world. Finally, we argue that we need to think through and acknowledge not just the identities we bring to the 'field' but also how these are linked to our investments in the broader geopolitical context of the neoliberal British academy, where we are both currently located. ${ }^{4}$ We suggest that thinking carefully about method in these ways gives us a much more thorough going notion of 
positionality, which is required if we are to address as well as redress current limitations in how we think and write about issues of development and the 'global south'. In the third section we outline an agenda for action for reconfiguring the scholarly track of academia to enable the development of a postcolonial method. Through the twists and turns of the paper we aim to explore the relationship between our (post)colonial research practices and the construction of the academy.

\section{Postcolonial development geography}

At its most general, postcolonialism refers to ways of criticizing the material and discursive legacies of colonialism. It presents a powerful critique of 'development' and offers an increasingly important challenge to dominant ways of apprehending north-south relations. McEwan (2002) identifies several core issues underlying a postcolonial approach. First, postcolonial critiques stress the need to recognize the ways in which the knowledge of those who were colonized are a central part in constructing imperial knowledges, and how this knowledge has nevertheless become localized, provincialized or erased. Second, these processes of knowledge construction are seen as central to the way in which wider geopolitical and economic power is secured by some groups in the north for their own benefit. Third, a postcolonial approach argues for the need for a radical reconstruction of history and knowledge production, demanding attention to a diversity of perspectives and priorities (McEwan, 2002: 128), which are elided both within the colonial project and the postcolonial present. Recognizing the voice of the subaltern then becomes a crucial methodological priority for postcolonial writers, who seek to decentre the north as the privileged position from which people speak (Bell, 2002) and to recognize agents and sites of knowledge outside the north (Loomba, 1998). And finally, a postcolonial perspective does not simply presume all the inhabitants of the third world as subaltern but, rather, recognizes how the postcolonial present is constituted through the simultaneous presence of a range of subject positions, differentially located along different axes of power across different locations. Hence, the subaltern cannot simply be mapped onto the contours of the 'third' world.

However, in the context of development geography, north-south relations take a particular and pressing form. ${ }^{5}$ The subject of development is a colonized subject who is artificially produced as distinct from the colonizer, and whose fate is often linked not to the histories of the production of inequalities but to its own lack of capacity. The intellectual authority of the colonial project therefore sits heavily on the shoulders of the northern development professional working 
in the south. Some counterweight to this authority may however be offered by 'engaged intellectuals' who:

seek to find solutions to issues of inequality, inequity and social justice rather than simply record and describe them. ...These all require not just acknowledging some elements of postcolonial theory, but working creatively and sincerely with them. Making connections and engaging in dialogues with others is not simply an intellectual counterweight to the divisive forces of imperialism, but a necessary part of a progressive politics (Mercer et al., 2003: 418).

This has to be part of challenging and changing the power hierarchies and material disparities upon which wider geopolitical inequalities rest.

\section{A method for postcolonial development research?}

So how can this progressive politics translate into developing a postcolonial method? And how can postcolonial approaches, which have primarily been developed within disciplines such as literary studies and history, be reformulated to undertake decolonized development research? Here we can draw upon the rich vein of writing on methods in development literature (Smith, 1999; Corbridge \& Mawdsley, 2003; Eade \& Rowlands, 2003; Hickey \& Mohan, 2004; ROBSON AND WILLIS, 1997), which problematizes power at multiple levels - from the interpersonal, to the global - and argues for the need to address those power relations actively (Mohan, 1999; Nagar $\&$ Ali, 2003; Chambers, 2005). Such approaches attempt to make research more participatory and accountable (Noxolo, 2006; Routledge, 2003; for some critiques see Cooke \& Kothari, 2001). Critical geographical literature on method too has much to contribute with its discussions around reflexivity (Rose, 1997; Cupples \& Kindon, 2003; Reid-Henry, 2003), the power of whiteness (Bonnett \& Nayak, 2003) and of representation (Cline-Cole, 1999; Tevara, 1999; Tembo, 2003). And finally, the extensive debates in feminist writing on methodology and ethics arise from similar imperatives and have much to offer towards postcolonial discussions on method (Butz \& Besio, 2004; Sharp, 2005). In particular, the detailed discussions of technique distilled from years of feminist practice can help to situate postcolonial research practice and to embed it in material relations. The mutually constitutive role of a variety of theoretical traditions in informing deliberations about a postcolonial method must, therefore, be acknowledged.

However, this vast literature on method still leaves us with two troubling issues. First, there is widespread concern that on the whole development research still does not speak to the

problems of those who 'are researched' (Dreze, 2002). ${ }^{6}$ Our experience is that despite many years of discussion on these topics, the way in which 'other places and people' are incorporated into 
research practice has not significantly altered and the impact of postcolonial (and postdevelopment) theorizing on the practices of 'doing' development research has been limited. ${ }^{7}$ Many of us working in development geography still only appear to be taking "package trips into the life of others' [missing Source/Ref? - ONLY A PHRASE WE ARE USING. IT IS NOT SOURCED FROM ANYWHERE IN PARTICULAR]. Is Jean Dreze (2002) then correct in asserting that social scientists are predominantly engaged in interacting with each other about issues and theories that bear little relation to the 'real world'?

In response, we suggest that a postcolonial method requires us to recognize the realities of the academy and how it shapes research. When Dreze (2002) suggests that the issues and theories that academics work with often bear little relation to the 'real world', it presupposes that academics are outside reality, that conversations in universities and conference halls are somehow 'unreal'. Although we feel seduced by this account, and we definitely feel sympathetic to Dreze's suggestions, when we have ourselves engaged in such conversations, we do often feel part of a 'real', perhaps a 'different real' to that we meet in the field but one which definitely has its own pressures, hopes and projects. So what is needed is an expansion of the notion of the 'real world' to include the 'reality' of the academy so that the academic world can be reshaped to acknowledge and be accountable to wider social and political formations. This would open up spaces for the academic activist to challenge and change material inequalities and injustices (Kitchin \& Hubbard, 1999; Massey, 2000). ${ }^{8}$ We therefore focus here on some of the reconfigurations of academic realities that would make place for more accountable research practices.

Second, it has been argued that this process of research interaction takes specific shape among northern academic development geographers who are distanced not only from the imperatives of people living in the south but also from geographical writing in the countries in which they practice their research. Thus, there is for instance disquiet about the increasing divide between Anglo-American research (and its forms of production) and the concerns of southern academics (see the issues of Gender, Place and Culture, 2002: 9(2); and Environment and Planning D, 2003: 21(2)). Arguably, the 'cultural turn' in Anglo-American geography, marked by increasing dependence on cultural and social theorists whose work does not 'travel' (see particularly Raju, 2002), and particular visions of political interventions (Sakho, 2003) have exacerbated these divides. ${ }^{9}$ 
This argument of the increasing divide, although true on the whole, comes with many caveats because many geographical researchers have lively and collaborative partnerships with geographers in other parts of the world. Besides, it is possible to overstate the case for nationally homogenous practices both within and among Anglo-American and non-Anglo countries. For instance, Krishnendu Ray (2003) argues that there are significant differences in institutional power between academics working within India (e.g. between those who work at institutional locations in metropolises, and in research institutes and universities, between colleges and central departments in universities) - in the resources available, the demands made on them and in the languages of communication. Similar differences resonate across the Anglo-American institutions too. Geographers are themselves embedded in complex matrices of power relations, producing their own inclusions and exclusions so that in comparing geographical work across different places, a nation is not 'the only legitimate category of analysis' (Ray, 2003: 2722). ${ }^{10}$ And, finally, using categories such as Anglo-American geography can sometimes be delimiting because locations, as Radhakrishnan (2003:22) suggests, 'are never simple, but rather multi-layered realities overdetermined by diverse cultural and political flows'.

Hence, although there is no simple and unproblematic way of distinguishing different geographical traditions, we would like to argue that there are still spaces and forms of knowledge that are not entirely determined through their relations with the north (Mufti, 2005) but also that our existing academic frameworks give us little room to validate these spaces and their distinctive world picturing. A postcolonial method therefore always involves holding in tension the mutual constitution of the north and the south and the importance of each for the other's formations, while also making room for a south that is not entirely constituted through its relation with the north. This is a move in the direction of Mufti's (2005:476) global comparativism 'that is a determinate and concrete response to the hierarchical systems that have dominated cultural life since the colonial era'.

We would therefore hold that the disjunctures between the ideas, methods and priorities of northern academics and their southern subjects (Dreze, 2002) sometimes overlap, sometimes intersect, and at other times may be distinct from that between northern academics and their southern counterparts, but that together they produce the contours of academic imperialism (Ake, 1979). Despite the examples of 'good practice' outlined above, there is still a:

lack of systematic research that explores the reasons behind our limited ability to excite the imagination of those whose struggles we study in the 'South', or to shift 
the forms, boundaries and languages of what is considered meaningful academic discourse (Nagar \& Ali, 2003: 366-367).

In the rest of the paper we want to examine some ways in which we could move towards such a meaningful academic discourse in which research 'opens up, makes space and crosses over'. We suggest that we need to explore the possibilities offered by expanding the notion of method to include three other aspects of the research process that have received little attention the questions we ask, how we theorize and how these are both embedded within the current geopolitical situation of the British academy which presently structures our research practice. Such an expanded notion of method is an essential first step towards making 'development' research more postcolonial because it takes account of the multiple realities that position academics not only in the 'fields' that they go to and the 'others' they come across, but also the structural frameworks of the academy which produces its own pressures of what constitutes academic work. This allows us to be more cognizant of the circumstances within which knowledge is produced and how it is connected to the 'opportunities, constraints and values embedded in our academic institutions' (Nagar \& Ali, 2003: 356; also see Robinson, 2003). It also enables us to question how the academy validates certain knowledges and excludes others and to discern the actual social and political processes through which this is achieved, as well as how they might be challenged. Finally, this involves a thoroughgoing notion of positionality, one where we 'consider our own positionalities in a much more difficult way than what has now become the customary laying out of the "me" in the usual "race" class and gender mantra' (Puwar, 2003: 27). Together they provide a framework for thinking about research in a holistic way and this is what a postcolonial method can offer.

In this paper we focus primarily on a postcolonial method for development geography as it arises in fieldwork-based research (though many of the issues we raise are not limited to this) for a number of reasons. First, there is a strong tradition of fieldwork in development geography so research practice and discussion of these practices is often skewed towards fieldwork methods. Second, and despite this tradition, there has been in recent times a tendency towards the 'abandonment of fieldwork by some researchers in favour of textual analyses' (Nagar, 2002: 180) following the critiques of fieldwork practices by researchers (Sidaway, 1992; Madge, 1993; Powell, 2002) and also in response to the literary and historical traditions of much early postcolonial work. While other texts - literary, historical secondary datasets - undoubtedly have much to offer, we want to argue for the continuance of fieldwork (and despite many of the issues we 
raise below) because it brings us most directly into contact with the everyday lives and realities of others, and through this democratic impulse has considerable potential for developing a dialogic version and accountable outcome for research (Sharp, 2005). ${ }^{11}$ This paper has grown out of an ongoing dialogue between us (the authors) on these issues over the last decade, on reflections on our research practices and dialogues with the many others with whom we have done research and lived out our lives. ${ }^{12}$ We use examples from our own work which are (primarily) embedded within debates about gender and development, a field where the intersection between feminist questions around method and development's interrogation of ethics/politics come so pressingly alive.

\section{Towards a postcolonial method}

In this section we want to focus on aspects of academic research practice that we think shape the problems of relevance and dialogue identified above and which could be altered to make development research more postcolonial because: 'self-criticality needs to embrace not only the substantive topics of research but also the practices involved in the doing of human geography' (Cloke, 2002: 591; emphasis added). We suggest the need to be more vigilant about how we frame our entry into academic work, how we frame our theories and how we frame our own investments in the academy. ${ }^{13}$

\section{Early beginnings, creating a dialogue}

The initial framing of a postcolonial method must be in terms of why the research is being conducted in the first place. If a postcolonial approach involves critical recognition of the material and discursive legacies of colonialism, then a postcolonial method has no option but to be a politically engaged method that forefronts the ethical issues of who gains from this research, and why. The researcher must be clear about the power relations, inequalities and injustices that enable and allow their research to occur and must be committed to working towards challenging these at different scales - the personal, the institutional, the global political.

It is only then that we can consider how the research question might be produced. We use the example of Parvati's PhD thesis (Raghuram, 1993) to explore the complexities of this issue. The thesis arose from two theoretical streams: development critiques of vulnerability (which shifted the focus of vulnerability from the microeconomic unit of the individual to that of a household) and feminist critiques of the household as a unit of equality. She postulated that the unit of vulnerability is usually a subset of the household and that social networks, which subsidized their welfare, supported such units. The topic emerged neatly from existing theoretical discussions in the 
British academy at the time. Parvati then went to India to conduct fieldwork. However, as the following excerpt from the thesis shows, things did not necessarily go well:

The agenda for the study was set by the researcher. My study uncovered areas that were considered important by the respondents whom I had addressed but could do little to redress. ...Further research and policies for the areas should focus on these agenda (Raghuram, 1993: 73).

This passage suggests that Parvati was aware of the limitations of her entry points, but like many new researchers, felt constrained by the conceptual framework adopted before the fieldwork. Her thesis agenda were shaped by the discursive frameworks of northern academic institutions because: "the production, distribution and consumption of "knowledge" on non-European [gender] issues is still governed by what has the "sanction" of Western academic centres of learning' (Pandurang, 2003: 121-2). As well as being linked to European theoretical traditions, it was also temporally situated so that, as Raju (2002: 176) suggests, the initial research questions were influenced by 'the flavours of the month'. So the thesis and the questions it set out to address were framed within northern academic imperatives 'with a consequent underplaying of the need to connect ideas with a broader range of political practice' (Cloke, 2002: 589) that might have been more relevant within the Indian fieldwork context. The hegemony that the academy holds over its members, especially students and others who feel disadvantaged within the academy (due to their class, race, gender backgrounds, perhaps?), to 'speak' in a certain way can trouble and delimit the scope of much development research.

This is, however, not to argue for a form of naïve localism or a simple particularism as no place is free from the play of power (Mohan, 1999). Rather, this example suggests the need to explore methods that will make our questions themselves more dialogic. This dialogue does not mean giving up your own position entirely, but starting from your own acknowledged position with openness to other positions. But in advocating dialogue we certainly do not presume that all difference can be dissolved to attain a complete (rational) understanding of the other, for there will always be degrees of incomprehensibility and continuing spaces 'in between'. But working through these inbetween spaces can bring moments of enlightenment; glimpses of the world through someone else's reality and a sense of the losses associated with privilege. From such moments of deep personal and political change more relevant research questions can arise, questions that can potentially challenge the 'master narrative' of northern-centred research. 
We would argue that a postcolonial method demands that research questions should be produced in dialogue so that project beginnings are embedded within and take account of the priorities of the researched and not delimited by the concerns of the northern 'experts' (Escobar, 1995). It is this imperative from the 'ground' that has the potential to make research more transformatory. Thus, what is needed is a redefinition of fieldwork to include the paradigmatic questions of the research and an assessment of their relevance (Tembo, 2003:231). But what academic configurations would be necessary for this to occur? What kinds of changes would be required of funding bodies, thesis committees, and research training and supervision sessions to make them flexible enough to accommodate changes wrought to the initial research questions as a result of an engaged dialogue with those who inhabit some of our fieldwork locations? These are some of the realities that often influence how research questions are currently produced and delimit the nature of research engagements, an issue we return to later in the paper.

But starting early also involves reflecting on and questioning the assumptions we make in our analyses in the field, showing how these are thoroughly dependent on the subjectivities that we as academics bring to our research. This is important because a postcolonial method must work towards problematizing the way that the world is known and challenging the hidden assumptions at the heart of northern research practice. These assumptions inform representations of knowledge, which are not neutral but charged with power that can influence the way in which our world is shaped. This link between representation, knowledge and subjectivities is illustrated through the following extract from an unpublished paper (Madge, c. 1993) Clare wrote sometime after submitting her PhD thesis (Madge, 1992). Based on fieldwork in The Gambia, her thesis focused on gender issues in the collecting economy of rural Gambian households but the representations in the thesis were influenced by her own subjective experiences of the academy:

Not long after returning to England from The Gambia I gave a seminar at Birmingham University entitled 'Gambian women: so strong a force?' This summed up many of the representations in my thesis text. I saw the women as powerful, centred, in control. However, I now feel that such representations were a 'describer's descriptions'. Some women did have power (sometimes) but not necessarily authority; some did have respect and control within the family (sometimes) but at a broader political and economic scale, many changes were beyond their control. So where were the representations in my thesis text coming from ${ }^{14}$ The representations were in part a reaction to the negative images of African women in the 1980s Eurocentric literature, which I had read before going to The Gambia (for example Cutrufelli, 1983). African women were portrayed as 'the poorest of the poor', people lacking 'agency' who were 'subjugated' and powerless. However, on arriving in The Gambia I was impressed by (what I labelled as) the power women seemed to exercise and esteem they appeared to command. However, the positive roles of African women that I represented were also probably a result of 
my own perceived relative powerlessness as a young woman in the lower ranks of the academic establishment. In comparison with how powerless I felt at that time, the Gambian women appeared confident and comfortable with themselves. In the only framework I then knew (self/other) I therefore perceived and represented the Gambian women as powerful. At this stage I did not link this 'naming' to the creation of an 'other' with me at the centre, the norm. The interesting issue, on reflection now, is that in trying to overcome one set of Eurocentric discourses I was actively creating a new set (Madge, c.1993).

A postcolonial method must therefore also involve early beginnings that challenge the experiences of analysing, representing, speaking and writing by which development research comes into being, highlighting how knowledge is a form of 'messy power' (cf Rose, 1997). If not, we silence our positionings with peril because our subjectivities not only make us privilege some angles, aspects and attitudes in our analyses but also occlude others which shape the contours of our postcolonial projects.

To summarize, a postcolonial method starts early on. It involves thinking about why we are doing research in the south in the first place, how we come to and produce our questions within a broader geopolitical context and how we analyze and represent our findings based on our subject positionings. But while these practices can help towards creating a more materially grounded and relevant research agenda, this framing of our entry into research is not enough. If postcolonialism is about a radical reconstruction of history and knowledge production, demanding attention to a diversity of perspectives and priorities, then we must also consider how we frame our dialogues with other texts, in particular, how we theorize.

\section{Questioning theory, theorizing practice}

A second way that we could move towards developing a postcolonial method in development geography is through expanding the notion of method to include theorization. The use of particular sets of theories, and more importantly theoreticians, in guiding research provides its own exclusions/inclusions (Spivak, 1988; Hooks, 1989; Chow, 1993). We begin with an example.

Some years ago, an Indian scholar was invited to present a paper on representations of the body in women's magazines in India at a famous centre for sociological research in a British university. After the presentation, a member of the audience expressed her disappointment that the scholar had drawn on the gurus of western social theory, in particular the analysis offered by Bourdieu, and that she had not used Indian theorists. If this scholar had not framed her analysis within 
theoretical frameworks familiar to the audience, we wonder, would she have been known to the academics at this university, or even invited to present a paper there? In short, as they stand, do our methods of knowing give little room to do anything more than 'recreate what we already assume, and... re-inscribe the politics of the status quo' (Passaro, 1997: 151)?

So in this section we suggest three ways of altering how we think/use theory to help us move towards a postcolonial method for development research, one which moves away from the status quo to 'provincialize' western theory (Chakraborty, 2000). First, we need to embed discussions of theory in practice by talking about theory as practice; second, we must recognize and reconfigure our methods of theorization; and finally, it is imperative that we contextualize theory. Together, we believe these steps (further discussed below) can help to destabilize the power of certain northern theories, open up the possibility of theoretical dialogue and enable a theorization that is more accountable to and embedded in the perspectives of those in the south about whom we theorize.

First we suggest that we need to consider theory as practice. We can do this by deconstructing the artificial opposition between theoretically-led approaches (where questions are led by key concepts and their development by theorists) and strongly empirical conceptions of knowledge (where explicit theorization is kept to a minimum) (Johnson et al., 2004). We argue that theory is part of all intellectual work. Indeed, all knowledge is inherently theoretical, as it involves making sense of the world through a process of abstraction. Knowledge construction involves editing in and editing out, holding in abeyance, choosing and reflecting, connecting and disconnecting, all part of the process of theorizing. However, because 'theory' has acquired a reified and highly valued status in academic work we sometimes lose sight of its relationship to our everyday practices. On the other hand, an overemphasis on knowledge as practice can also be problematic. A move to a client-oriented approach to knowledge, where consultancy and evaluation research becomes central to how the development industry operates in the search for 'simple solutions' to emergent problems, can sometimes lead to a disdain for theoretical knowledges (Mukherji, 2004). The critique of theory as belonging to the ivory tower can then be utilized to devalue abstracted thinking while at the same time reinscribing existing hierarchies about what constitutes knowledge. We therefore suggest that a postcolonial method must move away from treating theory and practice as oppositional because we all practice and live out our theories. 
Nevertheless theoretical knowledge in the academy does produce its exclusions/inclusions because theory is usually assumed to be archival knowledge, that which is written, stored and reproduced in particular forms, such as books and journal articles, and prized for its immanent value. Theory is often seen as distanced from the process of embodiment, for instance, from oral knowledges that are passed down from generation to generation and altered through practice. The processes of distanciation may become even more marked in writing theory, where a particular form of language is usually deployed, which while varying both within and around disciplines and approaches is marked by complexity and elaborated structures. It is also generated through particular sites, usually within academic institutions, though not necessarily so. Finally, theory is often referential - we often enter theory through theory (Dixon \& Jones, 2004) - so that with new layers of theorization and more and more references to texts that we have not read, more and more of us are left behind. Thus, 'theory' is not a set of disembedded practices, but is also a located and historical entity. Indeed, any theory is inevitably produced within, and may well be expressive of, the social hierarchies and inequalities of those who produce and circulate it. For these reasons, theory is always value-laden, even where it makes claims to objectivity or 'scientific' neutrality. But, we would like to suggest, these are problems about how we currently do theory, rather than theory per se.

So how might we go about reconfiguring our methods of theorization to meet the imperatives of postcolonial method? Towards this we suggest, following Johnston et al. (2004:98-99), that it is more fruitful to think of theorization as a process of abstraction by which details are simplified and links and relationships made more apparent, a kind of empirical disembedding, a move away from the complexity of the concrete, a shift from the particular to the general, a move away from a 'real' that is more complicated than we can possibly tell. All intellectual work involves abstraction - we define our research questions by selecting from the complex tapestry of everyday life. However, by being conscious of the processes of selection and our pre-knowledges that influence how we know what we know, we can justify our choices and see - and make visible to others - their effects. This achieves three things. First, it highlights the inevitability of theorization. Second, it outlines a method for 'doing theory', and describes it as a situated practice, and therefore helps to destabilize the power of 'Theory'. And third, it sheds light on the geographical and historical locatedness of particular ways of theorizing and issues of power as they are configured in the processes of abstraction. 
A crucial aspect of the destabilization of 'Theory' is a conscious movement between the different levels of abstraction involved in intellectual work. 'Theory' often secures its authority by working only at a highly abstracted level, one that we call 'highly theoretical'. For instance, even where the language of place is deployed in some versions of globalization theory, it is an abstracted place, one that is removed from the concrete. Counterposed to this version of theory is that outlined by Richard Johnson (1982) with regard to the writings of Karl Marx. Johnson argues that Marx's theoretical work focused on what was specific to the capitalist organization of labour in Britain of the mid-nineteenth century and carefully identified its links, continuities and differences with other societies in which class and property ownership were central, in order to demonstrate the validity of his argument. Marx therefore moved from universal categories (true of all history), to trans-epochal categories (true of all class societies), to categories with a narrower scope of reference true of a particular epoch or social regime of labour, usually the capitalist epoch. This movement between levels helped to produce specificity but also a generalizability: it began with a concrete historical and spatial formation, an analysis of the problem of the time which was contextually embedded, and from this moved between different levels of abstraction, returning finally to what this meant for a politics of change. So starting and returning to the concrete is what produces its explanatory value, helping us to explain our own concrete particularities. As Johnson et al. (2004:100) suggest:

Moving between levels includes re-embedding our theories in the denseness of the particular, so that our understanding of the particular is enhanced. Theorization, therefore, involves a double articulation: a move away from the complexities of individual instances to relatively simplified concepts, a move back to the concrete with our explanations enhanced... In concretion, our theory finds further correction or elaboration. The whole circuit is necessary: it doesn't help, except sometimes strategically, to privilege one level or the other.

What we suggest therefore is that we need a much more complete return to the concrete issues that we are theorizing because without it we limit the scope of the theory, we universalize theory while at the same time its ability to facilitate understanding is diminished. Most importantly, we encourage an evasiveness of the political implications of the theoretical ideas, and hence an incomplete accountability. In contrast, postcolonial theory suggests that it is not enough to provincialize northern theories; we also need to move southern knowledges to a level of abstraction that shakes up the idea that generality emanates from northern knowledge construction while particularity is synonymous with southern knowledges. Thus moving to a level of abstraction where the question resonates across space, where the place-specific can be illuminative, but not binding, and can enable us to think about a located praxis and its relations 
with trans-epochal alliances. This enables an understanding of the 'general account of the play of the particular in the universalizing processes of capitalist-imperial modernity' (Mufti, 2005: 485).

This brings us to the third point, the importance of contextualizing theory. The the above discussion suggests that a postcolonial method for development research must be one that moves between levels of abstraction, gaining its imperatives from the concrete as well as returning to the concrete. It is also one in which the spatial and temporal locatedness of theories must be made apparent. Empirical work usually makes explicit its moment of production; it locates itself both spatially and temporally. But we are rarely required to do this when we begin with 'Theory'. Just as we need a context for understanding our empirical work, we also need a historical and geographical contextualization for the theories that we use. This would make transparent and offer challenges to the scope of some Eurocentric theories. The often unstated claim to universality is one of the key problems of how many northern academics currently theorize. The hierarchies of power within the academy inscribe some theories with a global reach and universalistic scope while others are demarcated as - and see themselves to be - local. Indigeneity is then unhelpfully counterposed to universality, so that one speaks for the particular and the other for the general. We therefore argue for the need to make clear the context in which all theories are being produced and for theoretical work to identify its scope in ways similar to what we require and expect from empirical studies. ${ }^{15}$ And we need the academy to validate theories not for their universality, but for their locatedness.

Situating theory involves not only recognizing the current geographical and historical embeddedness and scope of theory, but also recognizing how theorization then incorporates people differently in different parts of the (post)colonial world. Global political economy and history have produced particular sites of development, and delimited the language of development to some sites while positioning some people as 'developers'. These demarcations affect who does development research, and where. For example, it is rare to see academics from India coming to Britain to undertake fieldwork; rather, they come to one of the British institutes to read development theory but return to India (or, less frequently, go elsewhere in the global south) to actually 'do' development research/work. ${ }^{16}$ These splits have political and emotional consequences. Thus, Wole Soyinka (quoted in Tiffin, 1991: xiv; original emphases), laments:

We have been blandly invited to submit ourselves to a second epoch of colonialism this time by a universal-humanoid abstraction defined and conducted by individuals whose theories and prescriptions are derived from the appreciation of their world and their history, their social neuroses and their value systems. 
Our academic politics means that very often we use places in the south as empirical sites and sites for application of theory, not as sites which generate their own abstractions, so that there is a "persistent alignment of theory/development dualism with the "West"/"third world" division" (Robinson, 2002: 531). Therefore:

when the 'who is speaking about what' issue is examined, development scholars (from the South and North) might prefer the term 'colonization' to 'cross fertilization' to refer to the way in which theory is formulated in geography. .... Only when, as a matter of course, social science research draws on theoretical insights and empirical examples from work on development (especially from the South) to understand and critique processes like globalization, will the postcolonial agenda become fully established. At this point development studies and political geography will reach the 'stage of full maturity' (Laurie with Calla, 2004: 112).

This critique of the 'culture of theory' has been the subject of many theorists working within a postcolonial frame (see Said, 1984, for extended discussions). For instance, Mufti (2005: 486) argues that it:

has become a last defence and redoubt for some of its inhabitants, a place of safety and refuge from the imperatives of what Said calls contrapuntality; it can be granted that "they" have literatures and other modes of cultural expression that are worthy of consideration, but only "we" have theory, the inclination to think in abstract and conceptual terms about language, culture, and the world and about the conditions of possibility of such knowledge itself.

There is, therefore, an urgent need for readings which 'concede the reality of other knowledges' and for research practices to avoid becoming 'an arena where readings take on a purely epiphenomenal significance long after the question of knowledge has been settled in favor of metropolitan knowledge'.[RADHAKRISHNAN, 2003: 24] Other worlds need to be recognized 'not merely as other histories but as other knowledges that question the legitimacy of metropolitan theory' (Radhakrishnan, 2003: 24).

However, by situating the critique of theory within a relatively high level of abstraction, the route into making these transcultural readings is not always made very clear. We would urge for a close look at theorization as part of research practice, as a method. To summarize, we advocate a postcolonial method which problematizes theorization and makes transparent both its context and the scope of its effects. This will help to destabilize the power of some theories, enable us to find points of theoretical intersection and commonality between different particular theoretical accounts and make place for a more dialogic version of theory that hears from and 
speaks to people in different parts of the world. But this 'postcolonial vision' will only be possible if we very firmly locate our research within the framing of our own institutional, geopolitical and material investments, the issue to which we turn next.

\section{Personal investments, neoliberal academy}

The final framing to consider as part and parcel of a postcolonial method is that of investments. Considering the early beginnings to a research project and questioning the manner of theorizing require a deep engagement and reconstruction of the multiple investments academics make in their research and the necessity of contextualizing these investments in particular settings which are structured by the global political economy, in the British case, by the increasing corporatization of higher education. It is necessary, as Sidaway (2000b: 265-66) argues, to consider the wider 'field' of academic production, because 'reflexivity is not primarily a project about self-knowledge but rather concerns itself with the conditions of production of the "self" and its knowledges'. Moreover, as Castree \& Sparke (2000: 222) urge, this is imperative as geographers have not addressed directly the way in which the British academy itself is embedded in flexible accumulation dynamics, which inevitably structures the way in which we do development research.

Thus, it is necessary to move beyond location to investments to examine the conditions within which we produce academic work, how we benefit from these conditions and how we might challenge them. As Chacko (2004) suggests, personal interest and career advancement are the twin engines that often drive a research topic, so a thoroughgoing positionality needs to take cognizance of how research is brokered by academic discourses and power. The issue of investments has to be considered part of academic practice because for many of us, our academic investments compete with, and are sometimes antagonistic to, our other investments. We as academics also have other investments - to our families, to political projects, to our mental and physical health, to the people whom we research, to our own ethics and conscience - that jostle with each other to produce our final version of knowledge. Recognizing and validating our other investments can help to place academic work in wider world contexts, to return academic practices to the complexity of the concrete and to recognize the many other people and places to which we are accountable. The question here is how do we prioritize our investments and which of our engagements do we consider most compelling? What we argue below is that given the importance of the world of work in our identity, we need the academy (as our site of work) to change 
the kinds of investments it requires of us and to put its 'geopolitical house in order' (Robinson, 2003: $65)$, in order to really enable us to practice postcolonial research.

But many changes to the institutional structure of the academy will be required to achieve this, because in 2005 political activism is increasingly difficult in the British academy. According to Ruddick (2004: 230) there are 'growing difficulties of being politically engaged beyond the confines of our institutions, that at best do not reward this activity, and at worse actively discourage it. Activism remains something of an illegitimate discourse'. The dynamics of contemporary capitalism, with the attendant marketization of education and commodification of knowledge, are 'splitting apart' the university as a space for a critical intellectual citizenship (Castree \& Sparke, 2000: 223-24). We therefore need the 'conditions of our labour' to be altered in order to allow us to invest in the kind of reality that Dreze privileges, a critical activist reality that takes its questions from the ground to guide our research. There are few academics who appear to be able to achieve this given the current productionism of the neoliberal research environment of the British academy.

In the UK, major grant awarding bodies, such as the Economic and Social Research Council (ESRC) and the British Academy, distinguish particular themes as priorities for research, so in order to get grants, research must be set within 'the contours set by their funders' and the outputs meet the requirements of such bodies (Cloke et al., 2004: 371). This, along with shifts in the system for research funding, whereby institutions are rewarded for particular forms of publications and in certain journals, has led to increasing institutional and personal pressure to target publications to these journals rather than to the multiple audiences appropriate to the project (Demeritt, 2000). The problem with the academy can then be summarized by the questions we all often are faced with: If we want to invest in the academy what do we have to disinvest from? Given the current institutional pressures of the academy, how possible is it to enter into a research process as an 'engaged intellectual' who makes connections and engages in dialogues with others (Mercer et al., 2003: 418)? Academics need 'to pause within their scholarly tracks and to think about how their own investments are ultimately linked to the very postures and productions they produce' (Puwar, 2003: 21).We conclude this paper by offering some suggestions for reconfiguring 'the scholarly track'.

\section{Where now? An agenda for change}


We have in this paper looked at some processes through which dominant research practices are reproduced and how they produce particular, usually northern biases, which serve to limit the scope of our development research. In this section, we outline some practical moves that we consider to be necessary if we are to attempt another 'world picturing' based on a postcolonial method. If we want to move away from being 'part of the problems, rather than being part of the solutions to the problems' (Edwards, 1989: 117), we have to think carefully about how we choose to position ourselves within the academic hierarchy and the world beyond it. This requires challenging and changing the nature of academic work, so that we can link our academic practices, ways of thinking and performing in the academy, with our way of being in the world. Below we outline some suggestions that we think will lay the basis for a postcolonial method in development geography.

First, we think that there should be greater funding opportunities to enable more dialogic research practice. For example, research-funding bodies could award funds for doing an extended period of fieldwork early on in the research, to identify appropriate questions, to make suitable alliances and to have a meaningful engagement with research communities. Additionally, collaborative research with southern research practitioners could be more readily funded. An example of good practice is the British Arts and Humanities Research Board's new initiative of collaborative doctoral awards based on active collaboration between higher education institutions and other bodies. Southern development practitioners too should be eligible for these forms of postgraduate funding and their southern experience should be validated on its own terms. Programmes such as the new collaborative programme announced by the UK's ESRC - along with the Department for International Development (DFID), move towards these objectives. However great care needs to be taken to ensure that such collaboration does not serve to expropriate and 'adopt' others while academics (particularly northern academics) retain the prestige, researchfunding and decision making authority about what constitutes knowledge. To support and encourage dialogic working practice is not simply a matter of flipping the coin. A new set of questions, languages, techniques, working practices and textual forms may develop and we will have to be humble in our efforts to work in collaboration. A 'double critical consciousness', tuneful to the realities of multiple locations and the power hierarchies that cross them, will be a challenging methodological approach to be working towards.

But to support a postcolonial method we also need to reconsider the way in which we theorize. We need to think about theoretical practices differently, evaluating theories for their 
ability to handle and explain concrete problems or issues and their ability to open up the possibility of praxis. Our theoretical methods should be less referential, less reverential and more contextualized so that theory does not become the playing ground for those who are already in the 'know'. This could potentially force enormous changes to our current disciplinary practices. Our knowledge construction and regulation, writing patterns, grant reviewing practices, supervision sessions, methodological training, external examining procedures and refereeing processes, that is, our professional practices, will all need reconfiguring for this. Changes to such academic cultural norms will not happen overnight and will involve enormous commitment and potential losses for some.

Finally, a postcolonial method requires full awareness of our investments in the geopolitical academy, which are not posited as oppositional to other investments. This requires greater recognition of the significance of policy relevant research and of steps towards breaking down divisions within and between academia and beyond. Practitioner-orientated journals, such as Development in Practice and Gender and Development, which provide a forum for debate between practitioners, policymakers, academics and activists, must be valued in RAE (research assessment exercise) culture. Routinized behaviour of individual academics must not be judged wholly by the norms of personal ethics without recognizing that these are also institutionally produced. A consideration of the banal processes of production of academic knowledges has to be a first step in rethinking the possibility of activism and genuine dialogue as part of academic research (Cloke, 2002:598). ${ }^{17}$

At the foreground of all these deliberations must be the haunting questions: just why is it so difficult to imagine and undertake a method of research that takes more concrete steps towards a more just and equal society for all? What personal, institutional and political changes must be undertaken to alter the 'conditions of labour' which will make this possible? And do we have the political will to create a postcolonial method for development research that has a better chance to 'make a difference'? These are urgent and necessary questions that we must ask ourselves if we are not simply to adopt postcolonialism as a comfortable buffer of inclusion of some sites and knowledges whilst reproducing dominant northern paradigms. Without this, postcolonialism might become yet another colonizing discourse and practice directed from northern centres of global power, one which plays to the political rhetoric of inclusion within the academy while adding further layers of delusion and amnesia to the material exclusion beyond it. 


\section{Acknowledgments}

Particular thanks to Reginald Cline-Cole, Clive Barnett and two anonymous SJTG referees for their thoughtful comments. We hope we have addressed some of their concerns but any shortcomings remain our own.

\section{Endnotes}

1 There have been interesting debates on research techniques that might be used in a postcolonial method, for example, over the value of action-orientated participatory approaches in development research (see Cooke \& Kothari, 2001). However, we would like to argue for an expanded definition of method that incorporates all the practices and preconceptions that shape the technique (see Johnson et al., 2004 for a detailed argument). We would also like to highlight the contingency of method, that is, there is no single appropriate postcolonial method as our method must be adapted to the specificities of the social, political, historical and material locations of the researcher and the people with whom they work. This is because the (post)colonial world of economies, institutions, cultures and minds is differentiated, uneven and interconnected. Finally, we do not have space here to discuss all aspects of what might constitute a postcolonial method and many important issues are left for another time, including techniques/ethics/leaving the field/ways of writing and so on.

2 We offer a located perspective on postcolonialism that suggests agendas for action within our own academic setting. Here 'we' refers to academic development geographers who we assume will be the main audience of this academic journal. We recognize problems with the use of the term 'we' in the paper as it is suggestive of a common constituency and can erase the socially, spatially and politically differentiated aspects of development research. We hope however, that the paper will speak, if differently, to our various readers.

3 However, due to space constraints this paper does not address key questions such as what defines a method as postcolonial, or why some of the issues discussed here should not be part of any (ethical) research project.

4 The 'field' is a highly contested term (Gupta \& Ferguson, 1997). Here we refer to it as the physical location and political/social terrain where research is undertaken, both of which are intimately connected to other sites of the researcher's world. Fieldwork then is not just a set of logistics but a whole range of human encounters occurring within the uneven social terrain of the field (cf Cloke et al., 2004: 4).

5 Since organizations such as the World Bank identify 'lack of knowledge' as a vector of development, it is important to intervene and argue for wider notions of knowledge that go beyond institutional approaches (see Zein-Alabdin, 2004, for an extended critique). On the other hand, the move to incorporate and institutionalize indigenous knowledges too raises alarm bells (Briggs \& Sharpe, 2004). In this paper we are presuming that engaged dialogue around knowledge construction is not driven by renewed desires to colonize the knowledge of others, but out of a recognition of the perils of parochial northern knowledge.

${ }^{6}$ This also problematically presumes that all development research focuses on those who are 'relatively powerless' but, given the extant critique of this position (Mohan, 1999, also see below), we do not engage with this element here.

7 Recent critical texts on practicing human geography (see for e.g. Cloke et al., 2004 and Scheyvens \& Storey, 2003) have begun to pay attention to disciplinary research practices, recognizing them as embodied and constituted through practices of travelling, dwelling, seeing, recording, narrating etc. They also have a more 'political' vision of why research might be undertaken in the first place and who might benefit from the process, and why. This framing will spill over into the practices of current development/geography students, hopefully changing the way in which development research is done in the future. 
8 Here we are not simply arguing that all academics should be involved in more activist fields. There is a whole scale of potential involvement with interconnected political and intellectual motivations. Rather, what we are arguing is that political and theoretical frameworks of research projects must not be solely contained within existing Anglo-American academic structures. This requires the academy to change to let us have other beginnings and it requires us to change so that we validate our ways of being which are not merely academic.

9 A number of attempts have also been made to respond to these divides, both through thinking through how social sciences in other parts of the world can become 'less fixated' by western paradigms (Mukherji, 2004), and by elaborating frameworks for other beginnings (Smith, 1999; Grossman, 2003).

10 The role of the displaced intellectual 'or those who left' is even more ambiguous - many become ethnic minorities in the white academy (Chow, 1993; Puwar \& Raghuram, 2003).

11 We recognize that all fieldwork is ultimately textualized but feel that fieldwork produces particular versions of accountability as we feel committed to 'personified others' we meet in fieldwork in very different ways than we feel to texts.

12 Parvati would like to thank Richard Johnson and Estella Tincknell in particular, for opening up cultural studies and its possibilities and politics to her. Clare would like to thank Tim Sayers, Ansu Badjie and Vahida Mohammad for opening up the possibility of another world picturing to her.

13 We like the word frame here, because it suggests that there may be more going on outside the frame but that at this moment and for this audience this is how we draw our boundaries around these issues. We would however argue for a 'plastic' frame, one that is malleable and is altered by pressures from both inside and outside the frame.

14 (and where are my representations coming from now in this paper)?

15 However, as Barnett (1999:290) suggests meaning is 'dependent on, but not finally reducible to local practices', so that contextualisation must itself become a reflexive practice, where contexts are understood as constituted through institutional and social practices.

16 We were particularly struck by this during a conversation with a British academic who obtained a Commonwealth scholarship in the 1960s to pursue a doctorate at an Indian university: how many people from the first world register for development studies degrees in the third world nowadays?

17 These manoeuvres for reconfiguring the academy should be accompanied by steps to include and take account of our reproductive responsibilities. For example, grants which permit us to bring our families with us for extended fieldwork periods.

\section{References}

Abrahamsen R (2003) African studies and the postcolonial challenge. African Affairs 102, 189-210.

Ake C (1979) Social Science as Imperialism: The Theory of Political Development. Ibadan University Press, Ibadan.

Barnett C (1999) Deconstructing context: exposing Derrida. Transactions of the Institute of British Geographers 24 (3), 277-93. 
Bell M (2002) Inquiring minds and postcolonial devices: examining poverty at a distance. Annals of the Association of American Geographers 92, 507-23.

Bonnett A, Nayak A (2003) Cultural geographies of racialization: the territory of race. In Anderson K, Domosh, M, Pile S, Thrift N (eds) Handbook of Cultural Geography, 300-12. Sage, London.

Briggs J, Sharp J (2004) Indigenous knowledges and development: a postcolonial caution. Third World Quarterly 25 (4), 661-76.

Butz D, Besio K (2004) The value of Autoethnography for field research in transcultural settings. The Professional Geographer 56 (3), 350-60.

Castree N, Sparke M (2000) Professional geography and the corporatisation of the university: experiences, evaluations, and engagements. Antipode 32 (3), 222-29.

Chacko E (2004) Positionality and praxis: fieldwork experiences in rural India. Singapore Journal of Tropical Geography 25, 51-63.

Chakraborty D (2000) Provincializing Europe: Postcolonial Thought and Historical Difference. Princeton University Press, Princeton.

Chambers R (2005) Idea of Development. Earthscan, London.

Chow R (1993) Writing Diaspora: Tactics of Intervention in Contemporary Cultural Studies, Indiana University Press, Bloomington.

Cline-Cole R (1999) Contextualising professional interaction in Anglo-(American) African(ist) geographies. In Simon D, Narman A (eds) Development as Theory and Practice, 95-133. Longman, Harlow.

Cloke PJ (2002) Deliver us from evil? Prospects for living ethically and acting politically in human geography. Progress in Human Geography 26, 587-604.

Cloke P, Cook I, Crang P, Goodwin M, Painter J, Philo C (2004) Practising Human Geography. Sage London.

Cooke B, Kothari U (2001) Participation: the New Tyranny. Zed Books, London.

Corbridge S, Mawdsley E (eds) (2003) Special issue on fieldwork in the tropics. Singapore Journal of Tropical Geography 24, 2.

Cupples J, Kindon S (2003) Far from being 'home alone': the dynamics of accompanied fieldwork. Singapore Journal of Tropical Geography $24,211-28$.

Cutrufelli MR (1983) Women of Africa: Roots of Oppression. Zed, London.

Demeritt D (2000) The new social contract for science: accountability, relevance and value in the US and UK science and research policy. Antipode 32, 308-29.

Dixon D, Jones JP (2004) What next? Environment and Planning A 36, 381-90.

Dreze J (2002) On research and action. Economic and Political Weekly, 37 (817), 2 March. 
Eade D, Rowlands J (2003) Development Methods and Approaches. Oxfam Publications, Oxford.

Edwards M (1989) The irrelevance of development studies. Third World Quarterly 11, 116-35.

Escobar A (1995) Encountering Development: The Making and Unmaking of the Third World, Princeton University Press, Princetown.

Gregory D (2004) The Colonial Present. Blackwell, Oxford.

Grossman M (ed) (2003) Blacklines: Contemporary Critical Writing by Indigenous Australians. Melbourne University Press, Melbourne.

Gupta A, Ferguson J (eds) (1997) Anthropological Locations: Boundaries and Grounds of a Field Science. University of California Press, Berkeley, California.

Hickey S, Mohan G (eds) (2004) Participation: From Tyranny to Transformation? Exploring New Approaches to Participation in Development. Zed, London.

Hooks B (1989) Talking Back: Thinking Feminist, Thinking Black. South End Press, Boston.

Johnson R (1982) Reading for the best Marx: history-writing and historical abstraction. In Centre for Contemporary Cultural Studies, Making History: Studies in History-Writing and Politics. Hutchinson, London.

Johnson R, Chambers D, Raghuram P, Tincknell E (2004) The Practice of Cultural Studies. Sage, London.

King A (2003) Cultures and spaces of postcolonial knowledges. In Anderson K, Domosh M, Pile S, Thrift N (eds), Handbook of Cultural Geography, 381-97. Sage, London.

Kitchin R, Hubbard P (eds) (1999) Research, action and 'critical geographies'. Area 31, 195-246.

Laurie N with Calla P (2004) Development, postcolonialism and feminist political geography. In Staeheli L, Kofman E, Peake L (eds), Feminist Perspectives in Political Geography, 99-112. Routledge, New York.

Loomba A (1998) Colonialism/post-colonialism. Routledge, London.

McEwan C (2002) Postcolonialism. In Desai V, Potter RB (eds). The Companion to Development Studies, 127-31. Arnold, London.

McEwan C (2003) Material geographies and postcolonialism. Singapore Journal of Tropical Geography 24, 340-55.

Madge C (c. 1993) The right to write about Africa. Unpubl paper, available at http://www.geog.le.ac.uk/staff/cm12/ .

Madge C (1993) Boundary disputes: comments on Sidaway. Area 25, 294-99.

Madge C (1992) Medicine, Money and Masquerades: Gender, Collecting and Rural Development in The Gambia. PhD thesis, [MISSING: [i] dept/inst; [ii] university [iii] town/county. GEOGRAPHY DEPARTMENT, BIRMINGHAM UNIVERSITY, BIRMINGHAM, UK]

Massey D (2000) Practicing political relevance. Transactions for the Institute of British Geographers 25, 131-33. 
Mercer C, Mohan G, Power M (2003) Editorial: new perspectives on the politics of development in Africa. Geoforum 34, 417-18.

Mohan G (1999) Not so distant, not so strange: the personal and the political in participatory research. Ethics, Place and Environment 2, 1, 41-54.

Monk J, Manning P, Denman C (2003) Working together: feminist perspectives on collaborative research and action. Acme 2, 91-106.

Mufti A (2005) Global comparativism. Critical Inquiry 31, Winter, 472-89.

Mukherji P (2004) Introduction: indigeneity and universality in social science. In Mukherji P, Sengupta C (eds) Indigeneity and Universality in Social Science, [missing pp nos. 15-65] Sage, Delhi.

Nagar R (2002) Footloose researchers, 'travelling' theories and the politics of transnational feminist praxis. Gender, Place and Culture 9, 179-86.

Nagar R, Ali F (2003) Collaboration across borders: moving beyond positionality. Singapore Journal of Tropical Geography 24, 356-72.

Nash C (2002) Cultural geography: postcolonial cultural geographies. Progress in Human Geography 26, 219-30.

Noxolo P (2006) Claims: a postcolonial geographical critique of 'partnership' in development discourse. Singapore Journal of Tropical Geography 27 (3), [this issue]

Pandurang M (2003) Conceptualising the emigrant Indian female subjectivity: possible entry points. In Puwar N, Raghuram P (eds), South Asian Women in the Diaspora, 87-98. Berg, Oxford.

Passaro, J. (1997) "You can't take the subway to the field!" "Village" Epistemologies in the Global Village', in A. Gupta \& J. Ferguson (eds), Anthropological Locations: Boundaries and Grounds of a Field Science, Berkeley, CA: University of California Press, 147-62.

Peake L, Trotz A (2002) Feminists and feminist issues in the South. In Desai V, Potter RB (eds), The Companion to Development Studies, 34-37. Arnold, London.

Powell RC (2002) 'The Sirens' voices: field practices and dialogue in geography. Area 34, 261-72.

Power M, Mohan G, Mercer C (2006) Editors' introduction: postcolonial geographies of development. Singapore Journal of Tropical Geography 27 (3), [this issue]

Pratt G (2002) Collaborating across our differences. Gender, Place and Culture 9, 195-200.

Puwar N (2003) Melodramatic postures and constructions. In Puwar N, Raghuram P, (eds), South Asian Women in the Diaspora 21-42. Berg, Oxford.

Puwar N, Raghuram P (2003) (Dis)locating South Asian women in the Academy. In Puwar N, Raghuram P (eds), South Asian Women in the Diaspora, 1-20. Berg, Oxford.

Radcliffe S (2005) Development and geography: towards a postcolonial development geography. Progress in Human Geography 29 (3), 291-98. 
Radhakrishnan R (2003) Theory in an Uneven World. Blackwell, Oxford.

Raju S (2002) We are different, but can we talk? Gender, Place and Culture 9, 173-77.

Ray K (2003) The nation betrayed, or about those who left. Economic and Political Weekly [MISSING volume/issue number 38, 26], June 28, [MISSING pp no...[2722? ONLY ONE PAGE LONG]

Raghuram (1993) MISSING REF [i] thesis title [ii] dept/instit [iii] university [iv] town/county COPING STRATEGIES OF DOMESTIC WORKERS: A STUDY OF THREE SETTLEMENTS IN THE DELHI METROPOLITAN REGION, INDIA DEPARTMENT OF GEOGRAPHY, UNIVERSITY OF NEWCASTLE-UPON-TYNE, NEWCASTLE-UPON-TYNE, UK.

Reid-Henry S (2003) Under the Microscope: fieldwork practice and Cuba's biotechnology industry: a reflexive affair? Singapore Journal of Tropical Geography 24, 184-97.

Robinson J (2002) Global and world cities: a view from off the map. International Journal of Urban and Regional Research 26 (3), 531-54.

Robinson J (2003) Postcolonialising geography: tactics and pitfalls. Singapore Journal of Tropical Geography 24, 273-89.

Robson E, Willis K (eds) (1997) Postgraduate Fieldwork in Developing Areas: A Rough Guide. In Monograph No. 9, Developing Areas Research Group of the Royal Geographical Society, with the Institute of British Geographers. [Not in text:DELETE?]

Rose G (1997) Situating knowledges: positionality, reflexivities and other tactics. Progress in Human Geography 21, 305-20.

Routledge P (2003) River of resistance: critical collaboration and the dilemmas of power and ethics. Ethics, Place and Environment 6, 66-73.

Ruddick S (2004) Activist geographies: building possible worlds. In Cloke P, Crang P, Goodwin M (eds), Envisioning Human Geographies, 229-41. Arnold, London.

Said E (1984) The World, the Text and the Critic. Faber and Faber, London.

Sakho H (2003) Looking deep into the surface: critical thinking and uncritical geography, Environment and Planning D: Society and Space 21, 142-47.

Scheyvens R, Storey D (eds) (2003) Development Fieldwork: A Practical Guide. Sage, London.

Sharp J (2005) Geography and gender: feminist methodologies in collaboration in the field. Progress in Human Geography 29, 304-09.

Sidaway JD (1992) In other worlds: on the politics of research by 'First world' geographers in the 'Third world'. Area 24, 403-08.

Sidaway JD (2000a) Postcolonial geographies: an exploratory essay. Progress in Human Geography 24, 591-612. 
Sidaway JD (2000b) Recontextualising positionality: geographical research and academic fields of power. Antipode 32 (3), 260-70.

Smith LT (1999) Decolonizing Methodologies: Research and Indigenous Peoples. Zed, London.

Spivak GC (1988) In Other Worlds. Essays in Cultural Politics. Routledge, London and New York.

Tembo F (2003) Multiple identities, representations and categorisations: experiences in the study of people's life-worlds in rural Malawi. Singapore Journal of Tropical Geography 24, 229-41.

Tevera DS (1999) Do they need ivory in Africa? Ruminations of an African geographer trained abroad. In Simon D, Narman A (eds) Development as Theory and Practice, 134-45. Longman, Harlow.

Tiffin H (1991) Introduction. In Adam I, Tiffin H (eds), Past the Last Post. Theorizing Post-Colonialism and Post-Modernism, vii-xvi. Harvester Wheatsheaf, Hemel Hempstead.

Townsend J in collaboration with Arrevillaga U, Bain J, Cancino S, Frenk S, Pacheco S, Pérez E (1995) Women's Voices From the Rainforest. Routledge, London.

Yeoh B (2003) Postcolonial geographies of place and migration. In Anderson K, Domosh M, Pile S, Thrift N (eds), Handbook of Cultural Geography, 369-80. Sage, London.

Zein-Alabdin EO (2004) Articulating the postcolonial (with economics in mind). In Zein-Alabdin E, Charusheela S (eds), Postcolonialism Meets Economics, 21-39. Routledge, London. 